\title{
OS ESCRAVAGISTAS NAS "FESTAS DA MODERNIDADE": O CENTRO DA LAVOURA E DO COMÉRCIO NAS EXPOSIÇÕES INTERNACIONAIS (1880-1888)
}

\section{Mariana Muaze ${ }^{I ; 2}$}

\section{RESUMO}

O artigo analisa a participação brasileira nas exposições internacionais oitocentistas, verdadeiras vitrines do progresso do capitalismo industrial, depois que o Império passou a ser representado nestes eventos pelo Centro da Lavoura e do Comércio, entre os anos de 1880 e 1888. Por meio da análise dos principais diretores do Centro da Lavoura demonstra-se que frações da classe senhorial, ligadas à cafeicultura do Vale do Paraíba, utilizaram as exposiçõ̃es e o próprio aparelho do Estado para ampliarem seus negócios e conquistarem novos mercados. Tratou-se da última tentativa dos grandes proprietários e comerciantes da bacia do centro-sul para aumentar seus lucros durante a crise da segunda escravidão.

\section{PATAVRAS-CHAVE}

Exposições internacionais - século XIX - crise da segunda escravidão - café - Brasil Império - Centro da Lavoura e do Comércio - clubes da lavoura.

1 Departamento de História da Universidade Federal do Estado do Rio de Janeiro (UNIRIO), Rio de Janeiro-RJ, Brasil

2 Doutora em História pela Universidade Federal Fluminense (UFF), com pós-doutorado pela Universidade de Michigan e pela Universidade de São Paulo (USP). Professora do Departamento de História da Universidade Federal do Estado do Rio de Janeiro (UNIRIO) e bolsista de produtividade do CNPq. Autora do livro "As memórias da viscondessa: família e poder no Brasil Império" (prêmio Arquivo Nacional de pesquisa 2007) e co-organizadora das coletâneas: "O Vale do Paraíba e o Império do Brasil nos quadros da segunda escravidão" (7 Letras, 2015), "O 15 de Novembro e a queda da monarquia" (Chão ed, 2019) e "A Segunda Escravidão e o Império do Brasil em perspectiva histórica” (Casa Leiria, 2020). E-mail: mamuaze@gmail.com.

Agradeço a Claudia Santos, Ricardo Salles, Rafael Marquese e demais colegas do grupo de pesquisa "A segunda escravidão e o Império do Brasil" (www.segundaescravidao.com.br), pelas sugestões feitas ao texto. 


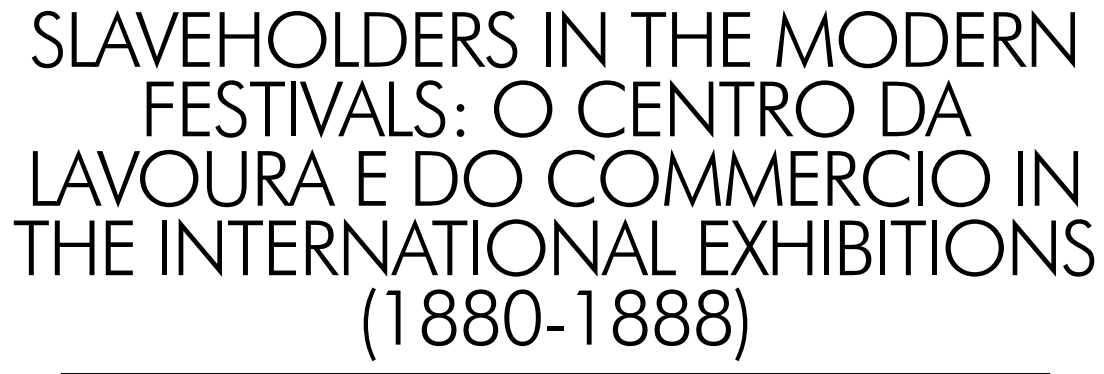

\section{ABSTRACT}

The article analyzes the Brazilian participation in 19th-century international exhibitions, true showcases of industrial capitalism, after the Empire began to be represented in these events by the Center of Agriculture and Commerce, between 1880 and 1888. Through the analysis of its main directors, it is possible to demonstrate that fractions of the master class, linked to coffee production in the Paraíba Valley, used the exhibitions and the state apparatus itself to expand their businesses and conquer new markets. It was the great slave-owners and coffee traders' last attempt to increase their profits during the crisis of the second slavery.

International exhibitions - XIX ${ }^{\text {th }}$ century - crisis of slavery - coffee - Brazilian Empire - Center of Agriculture and Commerce - agricultural clubs. 
partir da segunda metade do século XIX, as principais po-
tências europeias e os Estados Unidos organizaram exibi-
ções de grandes proporções e convidaram diversos países a montarem seus estandes com produtos que representassem suas respectivas nações. A primeira exposição universal ocorreu em Londres em 1851 e obteve enorme sucesso, alcançando a marca de 13.397 expositores e mais de 6 milhões de visitantes, reunidos na impressionante estrutura do Palácio de Cristal, construída especialmente para o evento ${ }^{3}$. Desde então, as novas "festas da modernidade", "exhibitiones universais da civilização burguesa" cresceram de importância e contribuíram fundamentalmente para a exaltação dos estados nacionais, da ideologia do progresso, da fetichização da mercadoria e do capitalismo industrial ${ }^{4}$.

Na segunda metade do século XIX, tais espetáculos se repetiram com grande magnitude em Londres (1862), Paris (1855, 1867, 1878, 1889, 1900), Viena (1873), Filadélfia (1876) e Chicago (1893), sempre encantando um público maior do que 5 milhões de pessoas por vez e contribuindo enormemente para a construção de um imaginário burguês, que exaltava os avanços da sociedade industrial. Tratava-se de grandes oportunidades de lazer, conhecimento científico e tecnológico, acordos políticos, investimentos econômicos e propaganda nacional, tudo reunido num só tempo e espaço.

Durante o Oitocentos, as exposições conviveram com uma heterogeneidade de formas, técnicas e ramos. $\mathrm{O}$ anúncio das diversas descobertas científicas (fotografia, máquina de costura, ferrovia, barco a vapor, telefone, eletricidade etc.) disputaram espaço com pavilhões que traziam a agricultura, a mineração e o artesanato em destaque. Os ecos da tradição também se fizeram presentes por meio de monarcas que usaram as exposições como vitrines de sua força política, a exemplo do príncipe Albert da Inglaterra, que se envolveu pessoalmente na organização do evento de 1851, e de Napoleão III, que se va-

3 TURAZZI, Maria Inês. Poses e trejeitos: a fotografia e as exposições na era do espetáculo. Rio de Janeiro: Funart: Rocco, 1995.

4 FOOT HARDMAN, Francisco. Trem-fantasma: a ferrovia Madeira-Mamoré e a modernidade na selva. São Paulo: Companhia das Letras, 2005. p. 62-63. 
leu da exibição francesa de 1855 para se reafirmar no trono, após dar o golpe de estado que implementou o Segundo Império ${ }^{5}$. O Brasil não ficou atrás. O próprio D. Pedro II viajou aos Estados Unidos, especialmente para o evento da Filadélfia, em 1876, que comemorava o centenário da independência da ex-colônia inglesa ${ }^{6}$. Recebeu elogios na imprensa, encontrou-se com o presidente americano Ulysses Grant, adquiriu a invenção de Graham Bell, e garantiu a continuidade das exportações do café brasileiro para seu maior mercado consumidor. Uma viagem um tanto proveitosa para consolidar sua imagem de monarca ilustrado, contudo insuficiente para evitar o desconforto de representar um império escravista numa república recém-saída de uma guerra civil, que resultara na abolição da escravidão.

Todavia, para aqueles que compunham a classe dominante do império, durante muito tempo, pertencer ao "mundo civilizado" não significava prescindir da escravidão. Muito pelo contrário! O compromisso com a manutenção da ordem e a expansão da civilização, que reuniu os interesses de homens e mulheres da classe senhorial e embasou a construção do estado nacional brasileiro ${ }^{7}$, serviu de esteio para a ampliação de uma verdadeira segunda da escravidão. 0 pilar dessa classe eram os grandes proprietários escravistas, especialmen-

5 Ibidem.

6 MACHADO, Marina Monteiro; MARTINS, Monica de Souza Nunes. A modernidade nas teias da floresta: o Brasil na exposição Universal da Filadélfia de 1876. Geosul, Florianópolis, v. 32, n. 65 , p. 68-86, nov. 2017.

7 MATTOS, Ilmar. O tempo saquarema. Rio de Janeiro: Acess, 1986.

8 O conceito de segunda escravidão foi cunhado pelo historiador norte-americano Dale Tomich e se baseia na percepção das diferenças entre a escravidão moderna, preponderante entre os séculos XVI e XVII, e aquela levada a cabo entre 1790 e 1888. A primeira escravidão se configuraria pelos monopólios mercantis, os impérios marítimos do mundo pré-moderno, quando o capitalismo estava em sua fase de acumulação primitiva de capital. A segunda escravidão representaria um sistema escravista mais maduro e veiculado ao mundo capitalista em ascensão desde o último quartel do século XVIII. Foi, em grande parte, pós-colonial, industrial, incentivadora de novas tecnologias (tais como ferrovias, transporte a vapor e modernas máquinas agrícolas), e apoiada pelos estados independentes e suas classes dominantes, que passaram a ter uma ligação direta com os poderes regionais e nacionais (BLACKBURN, Robin. Por que segunda escravidão? In: MARQUESE, Rafael; SALLES, Ricardo (org.). Escravidão e capitalismo histórico no século XIX: Cuba, Brasil e Estados Unidos. Rio de Janeiro: Civilização Brasileira, 2016. p. 13-54). Cf. também: TOMICH, Dale. Sob o prisma da escravidão: trabalho, capitalismo e economia mundial. São Paulo: 
te aqueles da região da bacia do Paraíba9, que concentravam cerca de $70 \%$ do total da população cativa do centro-sul cafeeiro e podiam diversificar seus negócios por meio de investimentos em casas comissárias, bancos e ferrovias, tornando-se verdadeiros potentados. Mas essa classe senhorial não era constituída apenas em seu fazer econômico. Seu pertencimento esteve assentado num habitus dito civilizado, com forte inspiração das formas de comportamento da aristocracia europeia e dos ideais de consumo burgueses, muito embora convivesse com as práticas escravagistas nas esferas pública e privada $^{10}$.

Com tal bagagem histórica, a opção levada a cabo pelo Estado Imperial foi ingressar nas "festas da modernidade" com o passaporte de terra de natureza exuberante, nação agrária vigorosa e potência mundial do café ${ }^{11}$. Não obstante, em fins dos anos de 1870, com uma crise econômica acentuada, a coroa desistiu de se manter à frente das exposições. A função foi assumida, uma única vez, pelo Clube da Lavoura de Campinas e, posteriormente, pelo Centro da Lavoura e do Comércio, durante praticamente toda a década de 1880.

Edusp, 2011; MUAZE, Mariana; SALLES, Ricardo (org.). A segunda escravidão e o Império do Brasil e em perspectiva histórica. São Leopoldo: Casa Leiria, 2020.

9 O conceito de bacia do Paraíba é entendido como o conjunto "da província do Rio de Janeiro, o Vale do Paraíba e o Oeste Velho paulista e a Zona da Mata mineira. Essa região alimentava ainda o porto e a praça do Rio de Janeiro, e, política e culturalmente, estava em estreita simbiose com a Corte imperial. Por isso, seguindo Orlando Valverde, talvez o mais correto fosse falar em Bacia do Paraíba, região que compreenderia todas essas áreas e suas configurações socioeconômicas" (MUAZE, Mariana; SALLES, Ricardo (org.). O Vale do Paraíba e o Império do Brasil nos quadros da segunda escravidão. Rio de Janeiro: 7Letras, 2015, p.14). Cf. VALVERDE, Valverde. A fazenda escravocrata de café. Revista Brasileira de Geografia, Rio de Janeiro, ano 29, n. 1, p. 37-81, 1967. Para uma obra clássica e fundamental sobre a região, consultar: STEIN, Stanley. Grandeza e decadência do café no vale do Paraíba. São Paulo: Brasiliense, 1961.

10 O habitus senhorial funcionava como uma visão de mundo, uma segunda natureza, na qual os futuros senhores desde a mais tenra idade experimentavam relações escravistas no seu cotidiano e intimidade e, portanto, não podiam se imaginar fora dele. Sobre o conceito de habitus, cf.: ELIAS, Norbert. O processo civilizador. Rio de Janeiro: Zahar, 1993. v. 1-2. Sobre o conceito de habitus aplicado à classe senhorial do Império, consultar: MUAZE, Mariana. As memórias da viscondessa: família e poder no Brasil império. Rio de Janeiro: Zahar, 2008.

11 TURAZZI, Maria Inês. Op. Cit.; FOOT HARDMAN, Francisco. Op. Cit.; PESAVENTO, Sandra J. Exposições universais, espetáculo da modernidade do século XIX. São Paulo: Hucitec, 1997. 
Este artigo demonstra que frações da classe senhorial do império ligadas à cafeicultura do Vale do Paraíba, por meio de suas instituições associativas, utilizaram as exposições internacionais e o próprio aparelho do Estado para ampliar seus negócios e conquistar novos mercados. Tratou-se do último impulso dos grandes proprietários e comerciantes da bacia do centro-sul para aumentar seus lucros num grave momento de crise da mão de obra escrava, esteio fundamental de sua riqueza.

\section{Com quem fica o convite para a festa}

A estreia do Brasil numa exposição universal ocorreu em 1862, quando Londres sediou o evento pela segunda vez. Na ocasião, o Império era o maior exportador mundial de café, com uma produção/ ano da ordem de 225 mil toneladas. Para escolher o que seria exibido no centro do capitalismo mundial, foi organizada a Primeira Exposição Nacional ${ }^{12}$, que ocorreu de 2 de dezembro de 1861 a 16 de janeiro de 1862, com a presença do imperador e de 437 expositores $^{13}$. Apesar do sucesso de público, mais de 50 mil visitantes, as máquinas agrícolas selecionadas pelo júri não puderam seguir para Londres devido à exiguidade do espaço físico no estande brasileiro, sendo substituídas por fotografias. As dificuldades de infraestrutura e recursos se mantiveram nas exposições universais de 1867 e 1873, sendo intensificadas pela queda da economia gerada pela crise bancária de 1864 e pela Guerra do Paraguai (1864-1870) e, posteriormente, agravadas com a seca nas províncias do Norte em 1878. Buscando equilibrar gastos, o

12 CUNHA, Antonio Luiz Fernandes da. Relatório geral da exposição nacional de 1861 e relatorios dos jurys especiaes, colligidos e publicados por deliberação da Commissão Directora. Rio de Janeiro: Typographia do Diário do Rio de Janeiro, 1862.

13 PESAVENTO, Sandra J. Op. Cit., p. 99. Realizar exposições nacionais para selecionar os produtos a serem expostos nos eventos internacionais se tornou uma prática. Em 1866, no prédio da Casa da Moeda, organizou-se a segunda e, em 1873, a terceira exposição nacional, na Escola Central do Largo de São Francisco, para preparar os estandes brasileiros em Londres e Viena, respectivamente (CATÁLOGO dos produtos nacionais e industriais remetidos para a exposição universal de Londres. Londres: Typ. de C. Whiting, Baeufort, 1862). 
governo brasileiro cancelou sua participação na exposição universal de Paris de 1878.

Apesar da desistência oficial, não demorou muito para que um grupo de cafeicultores e negociantes de Campinas solicitassem a montagem de um estande próprio na exposição. A proposta foi apresentada por meio do Clube da Lavoura de Campinas, fundado em 11 de fevereiro de 1876. Tratava-se, sobretudo, de uma tentativa dos novos produtores do Oeste Paulista de ampliarem sua visibilidade econômica no mercado internacional ${ }^{14}$. Em agosto, o barão de Indaiatuba foi eleito para dirigir o comitê organizador e contatou Luis Rodrigues d'Oliveira, negociante em Paris, para viabilizar o projeto junto aos franceses, no que foi bem-sucedido. A Exposição de Paris ocorreu de 20 de maio a 10 de novembro de 1878, no Champ de Mars, e recebeu 16 milhões de pessoas ${ }^{15}$.

Contudo, o Clube da Lavoura de Campinas participaria com estande próprio somente da exibição de 1878. Logo foi substituído pelo Centro da Lavoura e do Comércio, com sede na corte, que tomou para si a prerrogativa de representação nacional e a manteve por quase toda a década ${ }^{16}$. Desde então, as amostras de café enviadas foram das

14 Os seguintes sócios incentivaram a participação do Clube da Lavoura e do Comércio de Campinas na Exposição de Paris: Francisco Paulo Camargo, João Leite de Morais Cunha, Joaquim Pinto de Araújo Cunha, José Manuel Cintra, Martinho de Silva Prado, Prado e Chaves, José de Oliveira Bueno Prado, Visconde de Aguiar Toledo, Adolfo Julio de Aguiar Melchert, Albino Barbosa de Oliveira, Antonio Carlos Almeida Nogueira, Antonio Correia Barbosa, Antonio Egidio Souza Aranha, Antonio Pompeu Camargo, Barão Atibaia e o Barão Indaiatuba (PANG, Laura. The State and agricultural clubs of Imperial Brazil 1860-1889. 1981. Tese (Doutorado em História) - Vanderbilt University, Nashville, 1981. p. 200).

15 Sobre a participação do Clube da Lavoura de Campinas na Exposição de 1878, cf.: Diário de Notícias, Rio de Janeiro, 9 jul. 1877, 14 jul. 1877 e 15 out. 1877; D'OLIVEIRA. Luiz Rodrigues. Exposição do Club da Lavoura em França em 1878. Paris: Typographie Georges Charmerot, 1878. Relatório apresentado à diretoria; ORTIGÃO, Ramalho. Notas de viagem: Paris e a exposição universal (1878-79). Rio de Janeiro: Typ. Gazeta de Notícias, 1879.

16 Para este artigo, não foi possível averiguar como se deu efetivamente a passagem da concessão do Clube da Lavoura de Campinas para o Centro da Lavoura e do Comércio no que compete às exposições internacionais. No entanto, sabe-se que os principais membros de ambas as associações senhoriais estiveram reunidos durante o Congresso Agrícola de 1878, quando a exposição de Paris ainda estava em andamento. As mentalidades dos cafeicultores das quatro províncias do Centro-Sul não diferiram muito durante o Congresso, como iria ocorrer principalmente a 
quatro províncias do centro-sul e contaram com apoio logístico dos consulados brasileiros mais próximos aos locais de exibição. Percebe-se também o crescimento do volume dos investimentos em propaganda, infraestrutura e transporte, para que o café brasileiro pudesse ser conhecido além das grandes capitais ${ }^{17}$.

Em pouco tempo, o Centro da Lavoura e do Comércio chamou a atenção do público estrangeiro para a rubiácea brasileira, decorando luxuosamente os pavilhões, diplomando os plantadores dos melhores grãos, fazendo demonstrações de máquinas modernas, dentre outros recursos de valorização da imagem do café brasileiro no exterior. Além dos eventos nacionais preparatórios e das chamadas exposições universais, o centro promoveu o Brasil em várias outras

partir de 1884 (EISENBERG, Peter. A mentalidade dos fazendeiros no Congresso Agrícola de 1878. In: AMARAL LAPA, José Roberto do (org.). Modos de produção e realidade brasileira. Rio de Janeiro: Vozes, 1980. p. 167-194; MOTTA, José Flávio; LOPES, Luciana Suarez. Os cisnes cantam e a onda verde passa: os congressos agrícolas de 1878 e a demanda da lavoura por capitais. Economia e Sociedade, Campinas, v. 28, n. 2, p. 587-614, 2019; CARVALHO, José Murilo de (org.). Congresso Agrícola: edição fac-similar dos Anais do Congresso Agrícola, realizado no Rio de Janeiro, em 1878. Rio de Janeiro: Fundação Casa de Rui Barbosa, 1988).

A crise da escravidão atingiu os fazendeiros do Vale do Paraíba, em sua maioria filiados ao Centro da Lavoura e do Comércio, e os cafeicultores de Campinas e de outros municípios do Oeste de São Paulo de formas bastante diferentes. No primeiro caso, a crise era aguda e de difícil solução por conta da escassez de terras férteis, fronteira agrícola fechada, envelhecimento dos cafezais, dificuldades de financiamento bancário e investimento prévio de verdadeiras fortunas em escravos desde, pelo menos, a década de 1820. As mesmas dificuldades não ocorriam do lado paulista. A hipótese, que ainda carece de maiores comprovações, é que a hegemonia política dos cafeicultores do Vale do Paraíba, maioria esmagadora dos sócios e membros da diretoria do Centro da Lavoura, tenha falado mais alto no âmbito das negociações com o Ministério dos Negócios da Agricultura, Comércio e Obras Públicas e outras instâncias. A grandiosidade dos estandes, o salto na infraestrutura, a construção nacionalizada da propaganda do café e a renovação das concessões para a mesma instituição deixam entrever que a mudança foi muito bem-vista pelos dirigentes do Estado.

17 Para pesquisas futuras, seria interessante incluir, na análise do associativismo senhorial, as posições dos diferentes senhores dos clubes locais e futuros representantes do Centro da Lavoura e do Comércio no Congresso Agrícola do Rio de Janeiro. O evento teve início em 8 de julho de 1878, com a presença de mais de 400 delegados, representantes eleitos em reuniões de proprietários ou indicados pelas câmaras municipais e associações de classe locais, e foi convocado pelo ministro da Agricultura, Comércio e Obras Públicas, João Lins Vieira Cansansão de Sinimbu, quando o Partido Liberal retornava ao poder após mais de 10 anos seguidos de administração conservadora. 
exibições, sendo as de maior destaque: Exposição Continental de Buenos Aires (1882) (Figura 1), Exposição de Berlim (1882), Exposição de Viena e Trieste (1882), Exposição de Copenhagen (1883), Exposição Internacional de Colonização e Exportação de Amsterdam (1883) (Figura 2), Exposição Universal de São Petersburgo ${ }^{18}$ (1884), Exposição Universal de Beauvais (1885) e Exposição Universal de Anvers (Antuérpia, 1885) ${ }^{19,20}$.

18 PARANHOS JR., José Maria da Silva. Relatório da Exposição Brasileira de São Petersburgo (2/6/1884). Cadernos do CHDD, Brasília, DF, ano 12, n. 22, 2013.

19 PRADO, conselheiro A da. Exposição Universal de Antuérpia (Anvers): relatório. Rio de Janeiro: Typ. Imperial Nacional, 1886. CORNELI, René. Anvers et L'Exposition Universalle. 12. ed. Bruxelles: Typographie \& Lithographie Ad. Mertens, 1886.

20 Foram 27 exposições organizadas pelos representantes do café: "Exposição de Amsterdam, Londres, Paris, Bordéus, Zurich, Dinamarca, Nomeja, Trieste, Viena, Nova York, Boston, Montréal, Halifax, Quebec, Toronto, Genebra, Buenos Aires, Berlim, Agen e Willeneuve, Atenas, St. Louis, Bélgica, Louisiana, St. Petersburgo, Budapeste, Nova Orleans, Antuérpia”, quatro exposições nacionais com periodicidade anual de 1881 a 1884 e diversas exposições regionais (FERREIRA, Marieta de Moraes. A crise dos comissários de café do Rio de Janeiro. 1977. Dissertação (Mestrado em História), Universidade Federal Fluminense, Niterói, 1977). 


\section{Figura 1}

Quiosque de distribuição de café. Exposição de Buenos Aires, 1882

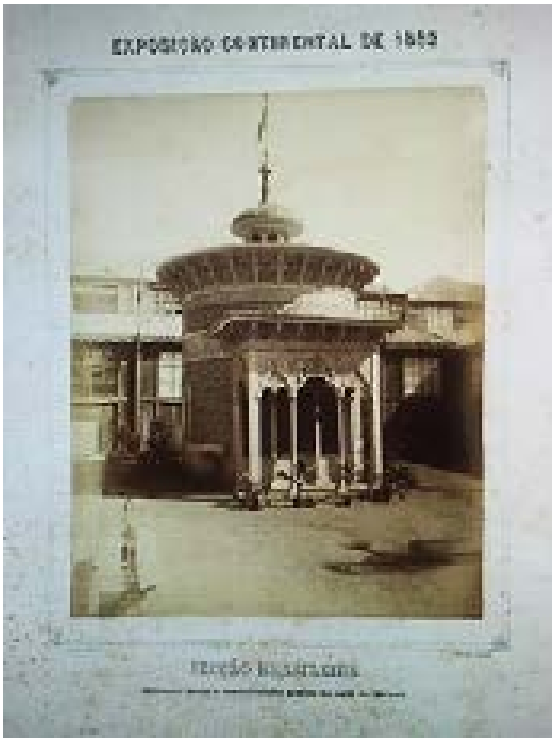

Fonte: Arquivo Nacional (foto Samuel Boote).

Figura 2

Estande brasileiro na Exposição de Amsterdam, 1883

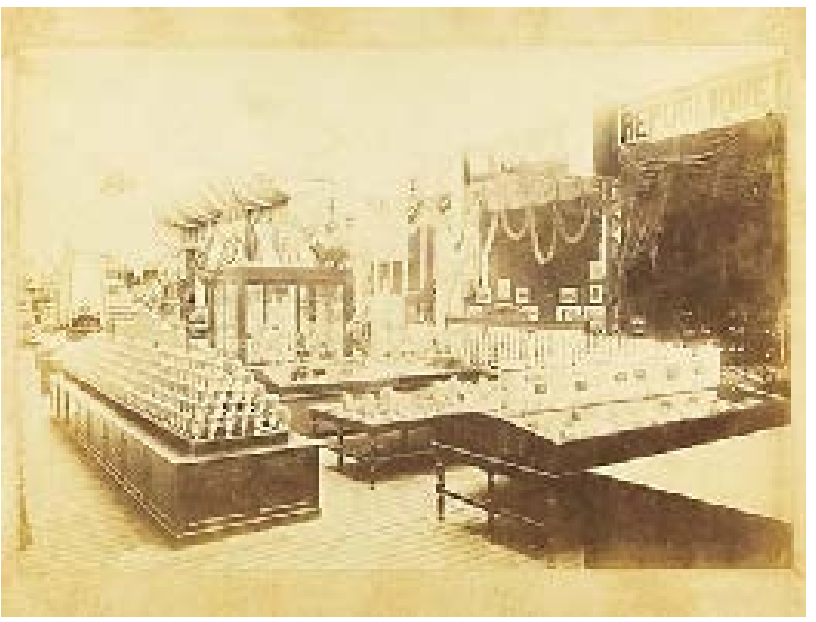

Fonte: Biblioteca Nacional. 
Assim, foi utilizada toda a sorte de publicidade para fechar bons negócios e garantir novos mercados. Na capital argentina, foi montado um quiosque para distribuição gratuita do café. Em Amsterdam, totalizam-se 1003 tipos de grãos e 64 prêmios, com destaque para o Centro da Lavoura e do Comércio pela variedade de tipos de café e para o Brasil pelo lugar de maior produtor mundial do gênero. Em São Petersburgo, distribuem-se 500 garrafas de licor, 8 mil libras de café em grãos e 700 exemplares do catálogo brasileiro, sendo construído um jardim de inverno para degustação dos melhores tipos. Os esforços foram recompensados com a visita do Czar Alexandre III e da família imperial russa, amplamente divulgada na imprensa. Em Anvers, os $550 \mathrm{~m}^{2}$ do pavilhão brasileiro receberam adornos e fotografias de paisagens nacionais, de estabelecimentos agrícolas, e das nossas vias férreas, sem contar as mil xícaras e pacotes de café oferecidos aos visitantes. Além disso, o público pôde vislumbrar uma série de imagens do fotógrafo Marc Ferrez das fazendas e dos cafeeiros, por meio do sistema Alfred Molteni, conhecido como Lanterna Mágica ${ }^{21}$. Encantado com o que vira na Rússia, José Maria da Silva Paranhos Jr., comissário brasileiro no evento, elogiou: "esta e a de Amsterdam também organizada pelo Centro da Lavoura e do Comércio - foram,

21 MUAZE, Mariana. A escravidão no Vale do Paraíba pelas lentes do fotógrafo Marc Ferrez. In: CARVALHO, José Murilo de; BASTO, Lúcia (org.). Dimensões e fronteiras do estado brasileiro no Oitocentos. Rio de Janeiro: Eduerj, 2014. p. 191-214; MUAZE, Mariana. Violência apaziguada: escravidão e cultivo do café nas fotografias de Marc Ferrez (1882-1885). Revista Brasileira de História, São Paulo, v. 37, n. 74, p. 33-62, 2017. 
sem dúvida, as maiores e mais completas exposições de café realizadas até hoje no exterior pelo Brasil”22.

\section{Os convidados de honra e algumas considerações sobre 0 associativismo senhorial}

Mas quem eram os dirigentes e sócios do Centro da Lavoura e do Comércio, instituição que ficou à frente das exposições internacionais mais importantes da década de 1880? Para responder a essa pergunta, vamos retornar à primeira forma de associativismo de proprietários de terras e escravos do centro-sul, além dos setores comercial e financeiro ligados ao café, ainda na década de 1870: o chamado Clube da Lavoura e do Comércio central ${ }^{23}$.

O Clube da Lavoura e do Comércio, com sede na Corte, foi fundado com 600 sócios inscritos, em 16 junho de 1871, em um suntuoso casarão na rua do Passeio, pouco mais de um mês depois que o gabinete conservador do visconde do Rio Branco apresentou no parlamento o projeto que libertava o ventre da mulher escrava. A situação era complexa, dividia opiniões e impulsionou muitos senhores do centro-sula se organizarem en quanto classe proprietária em diversos municípios.

Desde o início dos anos 1860, a defesa da escravidão foi se escasseando entre as nações europeias, fato que repercutia diretamente nas colônias e países independentes das Américas que ainda manti-

22 PARANHOS Jr., José Maria da Silva. Op. Cit.

23 Nas fontes consultadas, o Clube da Lavoura e do Comércio, bem como suas filiais, oscilaram a grafia entre Clube e Club. Para este artigo, decidi padronizar para a escrita atual. Também é interessante colocar que os clubes da lavoura municipais variaram muito na sua longevidade. Alguns foram criados em 1871 como reação à Lei do Ventre Livre e depois desapareceram, outros se mantiveram organizados até a década seguinte ou mesmo foram intermitentes. No caso do Clube da Lavoura central, encontrei menção no Diário do Rio de Janeiro até 7 de março de 1877, quando houve um pedido de doação de livros para a biblioteca do Clube lotada, na Rua do Rosário 35. 
nham a mão de obra servil ${ }^{24}$. Em 1865, com o fim da guerra civil e da escravidão nos Estados Unidos, D. Pedro II encomendou ao conservador Pimenta Bueno, Visconde de São Vicente, um projeto de libertação dos nascituros. Seu objetivo era se precaver de futuros problemas tendo em vista o sangrento exemplo do vizinho do norte.

O projeto de São Vicente só foi apresentado ao Conselho de Estado em abril de 1867, na vigência do terceiro gabinete liberal de Zacarias de Góes. Contudo, naquele momento, a discussão foi posta de lado, pois a conjuntura da Guerra do Paraguai já demandava esforços e negociações políticas bastante desgastantes. Terminada a guerra e iniciado o decênio conservador (1868-1878), o imperador instou o Visconde de Itaboraí, então presidente do Conselho de Ministros, e, posteriormente, seu substituto, o Visconde de São Vicente, a negociarem a proposta. Sem sucesso, a incumbência ficou para o Visconde do Rio Branco, José Maria da Silva Paranhos, que acabara de voltar do Paraguai e havia se oposto ao projeto em 1867. Todavia, no novo contexto, tendo a derrota dos confederados escravistas na Guerra Civil Americana, a Guerra do Paraguai e Lei Moret espanhola ${ }^{25}$ na bagagem, o projeto de libertação do ventre foi aprovado, com algumas adaptações, em 28 de setembro de 1871.

Como resultado, ocorreu o que Ricardo Salles chamou de "disjunção" entre as percepções de fazendeiros e estadistas sobre o contexto sociopolítico vigente ${ }^{26}$. De um lado, havia o imperador e uma parte ponderável dos dirigentes imperiais, com a percepção de que o império estava isolado no cenário internacional como país escravista e,

24 As últimas emancipações nas Américas foram: Curaçao e Suriname (1863), Estados Unidos da América (1865), Porto Rico (1873), Cuba (1886) e Brasil (1888).

25 A Lei Moret foi aprovada na Espanha em 4 de julho de 1870 e determinava a liberdade do ventre da mulher escrava e dos maiores de 60 anos nas colônias espanholas. Outros países já tinham assinado leis libertando o ventre escravo: Portugal (1773), Chile (1812) e Grã-Colômbia (1821) (BEIGUELMAN, Paula. A Formação do povo no complexo cafeeiro: aspectos políticos. São Paulo: Pioneira, 1977. p. 63-64).

26 SALLES, Ricardo. E o vale... Op. Cit., p. 81. Sobre a Lei do Ventre Livre como um momento-chave no debate "escravagismo" versus "abolicionismo", consultar: GEBARA, Ademir Gebara. O mercado de trabalho livre no Brasil. São Paulo: Brasiliense, 1986; PENA, Eduardo Spiller. Pajens da casa imperial. Campinas: Editora Unicamp, 2005. 
portanto, era preciso conduzir o abandono gradual e controlado do elemento servil. Não que a Coroa houvesse se tornado antiescravista, mas vislumbrava que, para conservar o sistema, era preciso fazer concessões. Do outro, estavam importantes setores da classe dominante da bacia do Paraíba ligados à agroexportação e à exploração maciça da mão de obra escrava. Estes compreendiam a situação política e econômica como estável e buscaram manter o status quo mediante representações no congresso ${ }^{27}$. Do ponto de vista do imperador e dos estadistas que o apoiavam, o ventre livre era uma concessão necessária para manter o poder senhorial e do estado, e evitar desdobramentos mais negativos no futuro. Para os senhores, tratava-se de um grave rompimento de contrato por parte da coroa.

Voltando ao Clube da Lavoura e do Comércio, afirmo que sua criação foi uma reação direta dos escravistas ao projeto de libertação dos nascituros recolocado em pauta em 1871. No congresso, eram representados pela ala do partido conservador hostil à proposta do gabinete Rio $\mathrm{Branco}^{28}$. Vislumbrando a gravidade da situação, os grandes senhores locais buscaram diversificar as formas de luta e fundaram uma associação central em defesa dos interesses agrários do centro-sul, pautando-a como de interesse nacional. Como discursou o sócio Antônio de Carvalho em nome do Clube:

Não é só o lavrador que tem que defender sua propriedade ameaçada, não é só o comerciante que compartilha a sorte do lavrador, é também o proprietário, o possuidor de apólices, o possuidor de títulos bancários, todos estes acompanharão a sorte da lavoura, se ela for próspera, todas as classes o serão, se for arruinada, todas se apresentarão arruinadas. $^{29}$

Para demonstrar sua força política, a cerimônia inaugural foi presidida por ninguém menos que o comendador José de Souza Breves, dono de um poderoso complexo cafeeiro escravista montado

27 Ibidem, p. 68-69.

28 CONRAD, Robert. Os últimos anos da escravatura no Brasil. 2. ed. Rio de Janeiro: Civilização Brasileira, 1978. p. 117.

29 Diário do Rio de Janeiro, Rio de Janeiro, ano 54, n. 196, p. 1, 17 jun. 1871. 
quando atuava no tráfico ilegal de escravos ${ }^{30}$. Ao seu lado na mesa, tomaram assento Caetano Furquim de Almeida, Augusto Soares de Miranda Jordão, Joaquim da Costa Ramalho Ortigão, Joaquim de Almeida Ramos (futuro barão de Almeida Ramos), o barão da Paraíba, personagens poderosos da classe senhorial ligada à bacia do Paraíba. Tal "comissão de frente" estava ali para impressionar, para mostrar à coroa o que ela tinha a perder e apontar que a luta seria boa, caso o projeto se mantivesse a sua revelia. Em discurso que arrancou aplausos da plateia, o Sr. Furquim de Almeida, capitalista e comissário de café de Vassouras, afirmava:

Desde o momento em que o governo apresentou seu projeto de emancipação na Câmara, [...] lavradores, comerciantes, proprietários, todos sentiram-se assustados por verem-se ameaçados em seus direitos, em sua propriedade, em tudo quanto tinham de mais caro. [...] Neste sentido reuniram-se as duas diretorias, a dos lavradores com a dos comerciantes, e combinaram em convocar esta reunião de ambas as classes e de todos aqueles que quiserem tomar parte na defesa de nossos direitos, para de comum acordo fundarmos uma associação, cujo fim é [...] defendermos os interesses da lavoura e todos aqueles os que com eles se acham ligados. [...] Queremos que respeitem nossa propriedade e que não ponham em risco nossa segurança, nossa vida e de nossas famílias. $^{31}$

As palavras de Caetano Furquim na primeira sessão do Clube da Lavoura central, bem como a dos deputados que defenderam os interesses escravocratas no parlamento ${ }^{32}$, deixavam claro que, naquele momento, a defesa da propriedade era uma espécie de hino para os membros da classe senhorial (que, aliás, duraria até o 13 de maio).

30 Entre os bens do comendador José Breves havia cerca de treze propriedades no termo de Piraí, outras quatro em Barra Mansa, duas em Angra dos Reis, e uma ligada à Volta Redonda. Contudo, em Angra dos Reis, não foi incluída a Ilha Comprida, deixada aos seus agregados no final dos anos de 1870. Sobre os Breves, ver: PESSOA, Thiago Campos. O Império da escravidão: o complexo Breves no vale do café (Rio de Janeiro, 1850-1888). Rio de Janeiro: Arquivo Nacional, 2015.

31 Diário do Rio de Janeiro, Rio de Janeiro, 16 jun. 1871.

32 Dentre os políticos foram citados: Andrade Figueira, o visconde de Itaboraí e Paulino Soares de Sousa Filho. 
Na percepção deste grupo, “estava em jogo a manutenção do controle senhorial - atual e futuro - sobre a sua mão de obra”33. Era preciso reagir ao projeto do governo, considerado "detonador de desordem", "perigoso" e "subversivo"34.

Durante a sessão, o Sr. Ramanho Ortigão aprovou o estatuto da nova associação, que incluía, dentre outras coisas, a contribuição de 100 mil réis dos sócios, e colocou em votação os cargos da primeira diretoria para um mandato anual ${ }^{35}$. Elegeram-se: o conde de Bonfim (presidente), o barão do Rio Negro ( $1^{\circ}$ vice-presidente), o barão da Paraíba ( $2^{\circ}$ vice-presidente), Pedro Luiz Pereira de Souza ( $1^{\circ}$ secretário, depois que Ramalho Ortigão declinou da posição alegando falta de tempo), José Feliciano de Moraes Costa ( $2^{\circ}$ secretário) e o barão de São Clemente (tesoureiro). Para consultores foram escolhidos: Dr. Caetano Furquim de Almeida, o comendador Jeronimo José de Mesquita, José de Sousa Breves, o barão de Ipiabas, o comendador José Pereira de Faro, barão de Prados, barão de Três Barras, comendador

33 SALLES, Ricardo. E o vale... Op. Cit., p. 127.

34 "O Clube do Comercio e da Lavoura acredita conscienciosamente: - Que o principio da liberdade dos ventres como está regulado na proposta do governo imperial, atualmente em discussão no parlamento, há de produzir na execução as mais desastrosas consequências. - Que proclamar livres os filhos das escravas e obrigar os senhores a cria-los e educa-los nem é justo para com uns, nem útil aos outros. - Que a indenização pecuniária oferecida é irrisória. Mas que nenhuma quantia em dinheiro pode compensar as desordens e perigos que ameaça o sistema proposto. Que a servidão até 21 anos em meio de numerosa população escrava será origem de ciúmes, de indisciplina, de desorientação do trabalho, que a tornarão uma impossibilidade prática. - Que quando praticável tal servidão seria a negação da liberdade proclamada e prepararia nos indivíduos libertos terrível elemento de subversão da sociedade em futuro bem próximo". Ata da reunião publicada (Diário do Rio de Janeiro, Rio de Janeiro, ano 54, $\mathrm{n}^{\circ}$ 196, 17 jun. 1871, p. 1). O Clube "estabeleceu como primeira tarefa fazer propaganda contra o movimento abolicionista e atuar como órgão repressor das possíveis rebeldias escravas”, além disso pretendia promover o café, reduzir impostos e encargos pertinentes à lavoura (FERREIRA, Marieta de Moraes. Op. Cit., p. 65).

35 O Clube seria composto de uma diretoria: presidente, vice, $1^{\circ}$ e $2^{\circ}$ secretários, tesoureiro e 40 consultores, anualmente eleitos. Dentre as normas, deveriam “\# 4 prestar todo o auxílio e socorro aos sócios do Clube em que disser respeito as suas relações com os escravos, solicitando para esse fim a ação da autoridade pública. [...] \#7 designar dentre os proprietários de cada freguesia do interior os membros que devem formar as comissões. [...] Das comissões locais art. 9-em cada freguesia será nomeada uma comissão de 3 dentre os mais importantes proprietários os quais serão no lugar os agentes da diretoria. [...] Diretoria se reunirá 3 vezes por mês ou mais quando necessário" (Diário do Rio de Janeiro, Rio de Janeiro, ano 54, nº 196, p. 1, 17 jun. 1871,). 
Manoel de Aguiar Vallim, Antonio Carlos Teixeira Leite e o barão de Tremembé.

$\mathrm{Na}$ ata de fundação, a primeira diretoria deixava claro que defenderia os interesses de seus membros por meio da "imprensa, do exercício do direito de petição e da criação de associações locais"36. $\mathrm{E}$, realmente, o fez. Até a aprovação final da Lei Rio Branco, em 28 de setembro de 1871, foram enviadas 33 representações à Câmara e onze ao Senado. ${ }^{37}$ Muitas delas foram publicadas em jornais da corte e das províncias buscando ampliar o apoio senhorial. Mandaram petições, além do Clube da Lavoura com sede na corte, os clubes municipais de: Vassouras, Valença, Bananal, Paraíba do Sul (assinada pelo barão das Três Barras), Rio Bonito (assinada pelo barão de Almeida Rosa), São Tomé das Letras, Resende, Piraí, Barra Mansa, Conservatória, Campinas, Cantagalo, Juiz de Fora e Campos ${ }^{38}$. A estratégia reivindicatória empregada espelhava a estrutura organizacional da nova associação senhorial, que tinha sua base de sustentação nos Clubes da Lavoura municipais ${ }^{39}$, presididos por grandes proprietários, que utilizavam dos poderes e polícias locais para manterem a ordem escravista $^{40}$.

36 Diário do Rio de Janeiro, Rio de Janeiro, ano 54, n. 196, p. 1, 17 jun. 1871.

37 ALONSO, Angela. Flores, votos e balas: o movimento abolicionista brasileiro (1868-1888). São Paulo:

Companhia das Letras, 2015.

38 O Diário do Rio de Janeiro publicou as seguintes petições: Bananal (22/06/1871), Vassouras

(25/07/1871, Vassouras 22/07/1871, Paraíba do Sul (24/05/1871), Piraí (15/06/1871, Conservatória

(23/06/1871), Valença (24/07/1871), Campinas (17/7/1871), Corte/Rio de Janeiro (24/07/1871), Cantagalo (26/07 e 28/07/1871) e Juiz de Fora (09/08/1871) (MARQUESE, Rafael. The Civil War in the United States and the crisis of slavery in Brazil. In: DOYLE, Don Harrison (org.). American Civil Wars: the United States, Latin America, Europe, and the crisis of the 1860's. Chapel Hill: University of North Carolina Press, 2017. p. 243). Sobre a reação à Lei do Ventre Livre: MIRANDA, Bruno da Fonseca. O Vale do Paraíba cafeeiro contra a Lei do Ventre Livre, 1865-1871. 2018. Dissertação (Mestrado História Social) - Universidade de São Paulo, São Paulo, 2018.

39 FERREIRA, Marieta de Moraes. Op. Cit.

40 Os clubes da lavoura mais estudados até o momento foram os de Campos e de Campinas. Para Laura Pang, há dois grandes impulsos constituidores de clubes da lavoura locais. Em 1880-1881, quando os senhores buscaram um diálogo com o gabinete Liberal de José Antônio Saraiva, pretenderam se preparar para a primeira legislatura de Joaquim Nabuco e o fortalecimento do abolicionismo. E, em 1884, quando já desacreditados da possibilidade de negociação, se tornam 
A discussão da lei Rio Branco foi dura no parlamento e "lançou região contra região"41. Enquanto as províncias produtoras de café resistiram veementemente, as outras com menor concentração de escravos e que viam decrescer significativamente seu número desde o fim do tráfico concordaram com a lei, a exemplo das do Norte. A reforma pretendida desencadeou debates acalorados que ocuparam a imprensa, teatros, reuniões públicas, além da Câmara e do Senado. Apesar da rápida e pesada mobilização dos escravagistas, a Lei do Ventre Livre foi aprovada por 61 votos a favor e 35 contra $^{42}$ e significou uma quebra do princípio legal do partus sequitur ventrem, segundo o qual o estatuto da criança seguia o da mãe cativa, alterando na essência as relações senhores-escravos. Além disso, representou uma ampliação de direitos dos escravos ao pecúlio e à compra da liberdade, uma vez que o direito costumeiro foi registrado. Contudo, nos anos que se sucederam à aprovação da lei, o discurso abolicionista, que começara a ganhar corpo na segunda metade da década de 1860, arrefeceu. Seu retorno vigoroso se deu no início dos anos de 1880, agora como um movimento social organizado em torno da bandeira do fim imediato e incondicional de todo o regime servil ${ }^{43}$.

Os anos de gabinetes liberais que se seguiram coincidiram com grandes avanços do movimento abolicionista e dos diferentes projetos abolicionistas em cena ${ }^{44}$. Com o início da década de 1880 , "todos os anos, foram criadas pelo menos três novas associações abolicionistas", com destaque para a Sociedade Brasileira Contra a Escravi-

mais reacionários, principalmente após o congresso de proprietários organizado como resposta ao projeto de Sousa Dantas (PANG, Laura. Op. Cit., p. 291).

41 CONRAD, Robert. Op. Cit., p. 114.

42 Conforme o jornal 25 de Março, o Clube da Lavoura de Campos dos Goitacazes constituiu uma comissão permanente autorizada a organizar um corpo de polícia municipal que poderá empregar "as providências que julgar necessárias contra aqueles que criarem imprensa abolicionista no município ou entretiverem relações com abolicionistas dentro dele e fora dele" (LAGE, Lana. Rebeldia negra e abolicionismo. Rio de Janeiro: Achime, 1981. p. 104-105).

43 SALLES, Ricardo. E o vale... Op. Cit.

44 Sobre os diferentes projetos abolicionistas, cf.: PINTO, Ana Flavia Magalhães. Escritos de liberdade: literatos negros, racismo e cidadania no Brasil oitocentista. Campinas: Editora Unicamp, 2018. 
dão, fundada em 7 de setembro de $1880^{45}$. A sociedade reunia José do Patrocínio, Joaquim Nabuco, André Rebouças e outros intelectuais e políticos, em sua maioria ligados à ala mais radical do Partido Liberal. O movimento ganhou mais fôlego com as "conferências emancipadoras", que aconteciam no Teatro São Vicente. Nelas discursaram diferentes palestrantes, muitos deles homens negros egressos ou não do cativeiro que participavam ativamente do debate, que recebia a cobertura da Gazeta da Tarde, ampliando ainda mais a difusão e circulação de suas ideias ${ }^{46}$. Naquele momento, não havia como negar, o partido abolicionista estava nas ruas ${ }^{47}$ !

Na década de 1880, a ideia da escravidão como uma instituição ultrapassada, desumana e arcaica, já há muito em vigor internacionalmente, não tardou a virar convicção para uma parte importante da opinião pública brasileira. Eram jornalistas, advogados, médicos, engenheiros e tantos outros profissionais liberais; mas também carroceiros, jangadeiros, cocheiros, vendedores e trabalhadores, egressos do cativeiro ou nascidos livres ${ }^{48}$, que por diferentes razões defendiam o fim da "nefanda instituição". Parte dos escravagistas, por sua vez, se apegava à Lei do Ventre Livre (antes tão combatida pelos mesmos) como tábua de salvação, afirmando que ela já era suficiente para garantir o fim da escravidão num "futuro próximo", não sendo necessário avançar mais. Outros proprietários, contudo, tentavam conciliar diante da inegável conjuntura político-social desfavorável

45 SANTOS, Claudia. O ativismo político da Confederação Abolicionista antes e depois do 13 de maio. In: LIMA, Ivana; GRINBERG, Keila; REIS, Daniel A. (org.). Instituições Nefandas: o fim da escravidão e da servidão no Brasil, nos Estados Unidos e na Rússia. Rio de Janeiro: Fundação Casa de Rui Barbosa, 2018. p. 294-326. p. 300.

46 PINTO, Ana Flavia Magalhães. Op. Cit.; ALONSO, Angela. Flores, votos e balas... Op. Cit.; SANTOS, Claudia. $\mathrm{O}$ ativismo... Op. Cit.

47 SALLES, Ricardo. Resistência escrava e abolição na província do Rio de Janeiro: o partido abolicionista. In: LIMA, Ivana; GRINBERG, Keila; REIS, Daniel A. (org.). Instituições nefandas: o fim da escravidão e da servidão no Brasil, nos Estados Unidos e na Rússia. Rio de Janeiro: Fundação Casa de Rui Barbosa, 2018. p. 266-293.

48 Entre 1873 e 1883 foram alforriados mais de 70 mil escravos no país, tal aspecto reduziu sensivelmente o número de proprietários de cativos, fazendo com que a manutenção da escravidão deixasse de ser um consenso nacional e acirrando consideravelmente as diferenças regionais em relação à dependência da mão de obra escrava. 
e incluíam a mão de obra imigrante em seus horizontes, todavia sem abdicar do discurso indenizatório. O enfrentamento de ideias e pessoas tomava as ruas da corte e agitava os ânimos. Nos municípios, os fazendeiros escravagistas se arregimentavam através dos Clubes da Lavoura locais, utilizando milícias e a própria polícia para perseguirem abolicionistas, escravos fugidos e quilombolas ${ }^{49}$.

Juntando os fatos, pode-se afirmar que, no início da década de 1880, quando a organização dos estandes brasileiros nas exposições internacionais foi assumida pelo Centro da Lavoura e do Comércio, estava em curso um forte desgaste da imagem das associações senhoriais, cada vez mais ligadas à violência e à manutenção da escravidão. Tal imagem prejudicava muito os novos negócios que se prospectavam nas exposições. A fundação de uma nova instituição era estratégica. Dar-se-ia continuidade ao projeto de incrementar as exportações brasileiras, contudo por meio de uma outra instituição não associada aos clubes da lavoura e ao "cancro roedor do Império"50.

A análise das diretorias e dos sócios fundadores do Clube da Lavoura Central e do Centro da Lavoura e do Comércio demonstra que a similaridade dos nomes das associações não era mera coincidência. A base social e política de ambas era a mesma: os grandes proprietários de terras e escravos, os políticos e homens de negócios ligados à bacia do Paraíba. Não obstante, não era mais possível para esses membros da classe senhorial do centro-sul apoiarem inadvertidamente a escravidão. Nos idos de 1880, eram poucos aqueles que não acreditavam ser a escravidão o "freio da civilização" e a abolição uma ação necessária e inevitável. Todavia, dessa certeza não decorria obrigatoriamente a defesa do fim total e imediato do

49 Foram vários episódios de violência, a exemplo da invasão da cadeia de Itu e linchamento de três escravos presos por mais de trezentas pessoas; a destruição da redação do jornal abolicionista 25 de Março e a perseguição de seu redator Carlos Lacerda em Campos dos Goytacazes, em 1884, e várias agressões em Campinas no mesmo ano. Cf.: MACHADO, Maria H. O plano e o pânico: os movimentos sociais na década da abolição. São Paulo: Edusp; Rio de Janeiro: Editora UFRJ, 2010; LAGE, Lana. Op. Cit.; MONNERAT, Tanize. Abolicionismo em ação: o jornal Vinte e Cinco de Março em Campos dos Goytacazes (1884-1888). Rio de Janeiro: Essentia, 2015.

50 A expressão foi cunhada por BONIFÁCIO, José. Representação à Assembleia Geral Constituinte e Legislativa do Império do Brasil Sobre a Escravatura. Rio de Janeiro: Typographia de J. E. S. Cabral, 1840. 
uso do "elemento servil". Muito pelo contrário, no discurso senhorial, a abolição deveria ser feita aos poucos, lentamente, estabelecendose um estatuto intermediário entre liberdade e escravidão, por meio da prestação de serviços e da tutela senhorial ${ }^{51}$. Ela também deveria ser concedida pelo poder senhorial e não "arrancada" pelo estado, como reclamavam os senhores. Não por acaso, essa foi exatamente a bandeira do Centro da Lavoura e do Comércio: o emancipacionismo lento e gradual, que prolongaria a escravidão para além da virada do século $\mathrm{XX}^{52}$.

Assim, em 1880, quando reunidos no sobrado do barão de São Clemente, no bairro do Flamengo, para a fundação do Centro da Lavoura e do Comércio ${ }^{53}$, intencionava-se dar uma nova roupagem, um "verniz civilizatório", aos velhos donos do poder ${ }^{54}$. O propósito do centro era anunciado:

resistir a esta anarquia que se levanta, determinar exatamente o curso mais útil à economia nacional, fundar em bases sólidas a sua indústria, alargar o círculo das relações comerciais, concitar a estima de outros países, afirmando-a nas conveniências da permuta, constituir enfim um estado rico, próspero e respeitado tal é a aspiração e o empenho primordial de nossa associação. ${ }^{55}$

O discurso apresentado não disfarçava um aspecto importante da ideologia e do modus operandi dos representantes da classe dominante do império em relação à política: a tentativa de conversão dos seus interesses privados em causas nacionais. Seus integrantes concebiam o estado como instrumento de seus interesses corporati-

51 MENDONÇA, Joseli. Entre a mão e os anéis. Campinas: Editora Unicamp, 1999. p. 121.

52 SWEIGART, Joseph Earl. Financing and making Brazilian exportation agriculture: the coffee factors of Rio de Janeiro. 1980. Tese (Doutorado em História) - University of Texas, Austin, 1980. p. 230.

53 Gazeta da Tarde, Rio de Janeiro, 15 nov. 1880. A casa do Barão de São Clemente ficava na rua Marquês de Abrantes 55, atual casarão do Colégio Bennett.

54 O jornal Gazeta da Tarde denunciava que o jornal O Cruzeiro havia sido o escolhido para representar os senhores e defender a nova instituição (Gazeta da Tarde, Rio de Janeiro, n. 110, 15 nov. 1880).

55 BREVE notícia sobre a primeira exposição do Café do Brasil. Rio de Janeiro: Clube da Lavoura e do Comércio, 1882. 
vos e atuavam dentro de tal lógica e espaço ${ }^{56}$. Portanto, para aqueles homens fundadores do Centro da Lavoura e do Comércio, ampliar as negociações e exportações do café no mercado internacional equivalia a zelar pelo bem da nação e não somente de sua classe. As permanências entre o Clube da Lavoura, que liderou petições senhoriais contra o Ventre Livre, e o Centro da Lavoura e do Comércio ficam mais evidentes quando comparamos suas diretorias e sócios fundadores (Quadro 1).

\section{Quadro 1}

Diretorias e sócios fundadores

\begin{tabular}{|c|c|c|}
\hline Clube da Lavoura/1871 & Centro LC/1880 & Vínculos familiares ou comerciais \\
\hline Christiano Ottoni & $\begin{array}{l}\text { Honório de Araújo } \\
\text { Maria }\end{array}$ & Cunhados \\
\hline \multirow[b]{2}{*}{ José de Sousa Breves } & $\begin{array}{l}\text { José de Sousa } \\
\text { Breves }\end{array}$ & Participa das duas associações \\
\hline & Eduardo Lemos & $\begin{array}{c}\text { Eduardo Lemos é sogro de Frederico } \\
\text { Gustavo de Oliveira Roxo, parente dos } \\
\text { Breves }\end{array}$ \\
\hline Barão de São Clemente & $\begin{array}{l}\text { Barão de São Cle- } \\
\text { mente }\end{array}$ & Participa das duas associações \\
\hline Antônio Teixeira Leite & $\begin{array}{l}\text { Honório Augusto } \\
\text { Ribeiro }\end{array}$ & Sócios \\
\hline \multirow{2}{*}{ Barão de Tremembé } & $\begin{array}{l}\text { João Valverde de } \\
\text { Miranda }\end{array}$ & $\begin{array}{c}\text { O pai de João Valverde é sócio do barão } \\
\text { de Tremembé }\end{array}$ \\
\hline & $\begin{array}{l}\text { Francisco Inácio de } \\
\text { Araújo Ferraz }\end{array}$ & Cunhados \\
\hline Caetano Furquim de Almeida & Hermano Joppert & Caetano Furquim é sogro de Joppert \\
\hline
\end{tabular}

56 MATTOS, Ilmar. Op. Cit. 
Mariana Muaze Almanack, Guarulhos, n. 29, eao0221, 202I

Os escravagistas nas "festas da modernidade": o centro da lavoura e http://doi.org/10.1590/2236-463329eaoo22I do comércio nas exposições internacionais (1880-I888)

\begin{tabular}{|c|c|c|}
\hline $\begin{array}{l}\text { Augusto Soares } \\
\text { Miranda Jordão }\end{array}$ & $\begin{array}{l}\text { Carlos Augusto } \\
\text { Miranda Jordão }\end{array}$ & Augusto é pai de Carlos Augusto \\
\hline $\begin{array}{c}\text { Joaquim da Costa Ramalho } \\
\text { Ortigão }\end{array}$ & $\begin{array}{l}\text { J. C. Ramalho } \\
\text { Ortigão }\end{array}$ & $\begin{array}{c}\text { Participa das duas associações. É sócio } \\
\text { do barão de Guararema, irmão de José } \\
\text { Breves }\end{array}$ \\
\hline
\end{tabular}

Os dados coletados demonstram que, dentre os doze membros da primeira diretoria do Centro da Lavoura e do Comércio, $75 \%$ (oito indivíduos) eram os mesmos ou tinham relações familiares e/ou negócios com os sócios fundadores do Clube da Lavoura, de 1871. Conforme foi verificado na pesquisa, os criadores do centro pertenciam a importantes famílias cafeicultoras da bacia do Paraíba ou eram sócios de casas comissárias a elas conectadas ${ }^{59}$. Tal estrutura social era bastante semelhante à do Clube da Lavoura. Todavia, o centro, apesar de permanecer endógeno à classe senhorial, apresentava uma composição mais variada em termos de atividades econômicas, incluindo personagens com interesses que ultrapassavam a produção, negócios e comércio de café, como as áreas bancárias, de transporte, de seguros, mineração e imigração.

Além disso, como pode ser conferido no Quadro 2, alguns membros se tornaram acionistas ou diretores das mesmas empresas, a exemplo da Cia. E. F. Príncipe do Grão-Pará e da Cia. de Minas de Assuruá, e ocuparam cargos em companhias do governo. Tal aspecto demonstra que as redes sociais e de negócios dessas famílias se espraiavam por outros espaços e associações para além de suas empresas originais, do Clube ou do Centro da Lavoura. O Real Gabinete Português de Leitura, por exemplo, foi a instituição social preferida dos três únicos portugueses do Centro.

57 SWEIGART, Joseph. E. Coffee factorage and the emergence of a Brazilian capital market, 1850-1888.

New York: Garland, 1987. p. 286-293.

58 D’OlIVEIRA, Luiz Rodrigues. A exposição do Clube da Lavoura em França em 1878. Paris: Typ.

Georges Clarmerot, 1878.

59 SWEIGART, Joseph Earl. Financing and making... Op. Cit., p. 286-293. 


\section{Quadro 2}

\section{Redes familiares, de sociabilidade e de negócios}

\begin{tabular}{|c|c|c|}
\hline $\begin{array}{c}\text { Diretores do Centro } \\
\text { da Lavoura em 1880 }\end{array}$ & Rede familiar e societária & Negócios e vínculos empresariais \\
\hline $\begin{array}{c}\text { *Francisco Inácio de } \\
\text { Araujo Ferraz, barão } \\
\text { de Araújo Ferraz em } \\
1882\end{array}$ & $\begin{array}{c}\text { Filho de Inácio de Araujo Ferraz } \\
\text { e cunhado do visconde de Tre- } \\
\text { membé (fazendeiro em Taubaté } \\
\text { SP). }\end{array}$ & $\begin{array}{c}\text { Sócio da Ferraz \& Astolfo (1873-77), da } \\
\text { Araujo Ferraz \& Cia. (1877-); membro } \\
\text { do Conselho Fiscal da Cia. Docas d. } \\
\text { Pedro II (1880); vice-presidente do fun- } \\
\text { do de pensão Monte Pio Geral (1884); } \\
\text { acionista da Cia. E. F. Príncipe do Grão } \\
\text { Pará (1886); diretor do Banco do Brasil } \\
\text { (1887). }\end{array}$ \\
\hline $\begin{array}{c}\text { Joaquim de Melo } \\
\text { Franco }\end{array}$ & $\begin{array}{c}\text { Filho de Manuel de Melo Franco } \\
\text { e sócio do 2 }{ }^{\circ} \text { barão de Pitangui } \\
\text { (fazendeiro em MG). }\end{array}$ & $\begin{array}{c}\text { Sócio da Mello \& Armond (1858-1870) e } \\
\text { da Eloy da Câmara \& Cia. (1880, enge- } \\
\text { nho de cana em Resende); proprietário } \\
\text { da Joaquim de Melo Franco (1870-); } \\
\text { secretário da Cia. União e Indústria } \\
\text { (1880). }\end{array}$ \\
\hline
\end{tabular}




\begin{tabular}{|c|c|c|}
\hline "Hermano Joppert & $\begin{array}{c}\text { Filho de Gustavo Joppert e genro } \\
\text { de Caetano Furquim de Almeida } \\
\text { (banqueiro em Vassouras e em- } \\
\text { preendedor de ferrovias). }\end{array}$ & $\begin{array}{l}\text { Sócio da Furquim, Lahmeyer \& Cia. } \\
\text { (1867-78), da Furquim, Joppert \& Cia. } \\
\text { (1878-86), da Joppert, Furquim \& Cia. } \\
\text { (1886-); acionista da Cia. Comércio de } \\
\text { Café (1878); tesoureiro da Associação } \\
\text { Comercial do Rio de Janeiro (1884); } \\
\text { membro da comissão de contas da } \\
\text { seguradora Caixa Geral das Famílias } \\
\text { (1884), incorporador da Cia. Lavoura, } \\
\text { Indústria, da Colonização (1885, Barra } \\
\text { do Piraí), da Cia. Agrícola e Colonizado- } \\
\text { ra de Vassouras (1885), da Cia. Engenho } \\
\text { Central de Santa Rosa (1885, Campos), } \\
\text { da Cia. Engenho Central da Pureza } \\
\text { (1885, São Fidelis) e da Cia. Agrícola de } \\
\text { Sapucaia (1887, Sapucaia); presidente } \\
\text { do Banco União de Crédito (1886) e da } \\
\text { Cia. Engenho Central do Bracuí (1888, } \\
\text { Angra dos Reis); conselheiro fiscal da } \\
\text { Cia. E.F. Macaé e Campos (1887) }\end{array}$ \\
\hline $\begin{array}{l}\text { "Carlos Augusto de } \\
\text { Miranda Jordão }\end{array}$ & $\begin{array}{l}\text { Filho de Augusto Soares de } \\
\text { Miranda Jordão (fazendeiro em } \\
\text { Paraíba do sul e banqueiro). }\end{array}$ & $\begin{array}{l}\text { Plantador em Paraíba do sul, sócio } \\
\text { da Miranda Jordão \& Cia. (1879), } \\
\text { proprietário da Cia. Metropolitana de } \\
\text { Imigração, acionista da Sociedade de } \\
\text { Mineração de São José d'El Rei } \\
\text { (1885, Minas Gerais) }\end{array}$ \\
\hline $\begin{array}{l}\text { "Eduardo Rodrigues } \\
\text { Cardoso de Lemos } \\
\text { (português) }\end{array}$ & $\begin{array}{l}\text { Filho de Victor Rodrigues Car- } \\
\text { doso, com laços familiares com } \\
\text { as famílias Oliveira Roxo e Sousa } \\
\text { Breves (fazendeiros em Angra } \\
\text { dos Reis e Piraí). }\end{array}$ & $\begin{array}{l}\text { Sócio da Roxo \& Filhos (1864-67), da } \\
\text { Roxo, Freitas \& Cia. (1867-69); da Roxo } \\
\text { Irmãos \& Cia. (1870-73); da Roxo, } \\
\text { Monteiro \& Lemos (1873-77) e da Roxo, } \\
\text { Lemos \& Cia. (1877-84); presidente do } \\
\text { Real Gabinete Português de Leitura } \\
\text { (1877), secretário da Cia. Comércio de } \\
\text { Café (1878) e diretor do fundo de pen- } \\
\text { são da Monte Pio Geral (1882). }\end{array}$ \\
\hline $\begin{array}{l}\text { "Honório de Araujo } \\
\text { Maia, barão de Araujo } \\
\text { Maia em } 1884 .\end{array}$ & $\begin{array}{l}\text { Filho de José Joaquim Araújo } \\
\text { Maia, sobrinho do barão de } \\
\text { Madalena, cunhado de Chris- } \\
\text { tiano Ottoni e fazendeiro em } \\
\text { Teresópolis. }\end{array}$ & $\begin{array}{c}\text { Fazendeiro em Teresópolis, sócio da } \\
\text { Cunha \& Maia (1867-73), da Araujo } \\
\text { Maia \& Irmãos (1874-84), tesoureiro da } \\
\text { Cia. Ferro-Carril de Pernambuco (1876), } \\
\text { incorporador da Cia. E.F. Príncipe do } \\
\text { Grão Pará (1881) e conselheiro fiscal da } \\
\text { Cia. de Minas de Assuruá (mineradora } \\
\text { baiana), diretor do Banco do Brasil } \\
\text { (1887). }\end{array}$ \\
\hline $\begin{array}{l}\text { João Valverde de } \\
\text { Miranda }\end{array}$ & $\begin{array}{c}\text { Filho de João Pereira Valverde } \\
\text { de Miranda, sócio do visconde } \\
\text { de Tremembé (fazendeiro de } \\
\text { Taubaté). }\end{array}$ & $\begin{array}{c}\text { Sócio da Miranda \& Monteiro (1870-73) } \\
\text { e da Miranda \& Tremembé (1873-79), } \\
\text { proprietário da João Miranda \& Cia. } \\
\text { (1880-). }\end{array}$ \\
\hline
\end{tabular}




\begin{tabular}{|c|c|c|}
\hline $\begin{array}{l}\text { "Joaquim da Costa } \\
\text { Ramalho Ortigão } \\
\text { (português) }\end{array}$ & $\begin{array}{l}\text { Filho de Joaquim da Costa } \\
\text { Ramalho Ortigão, genro do barão } \\
\text { do Engenho Novo (fazendeiro } \\
\text { de Valença) e sócio do barão de } \\
\text { Guararema (fazendeiro em Piraí } \\
\text { e irmão de José de Souza Breves). }\end{array}$ & $\begin{array}{l}\text { Sócio da Sousa Breves \& Cia. (1875-79) } \\
\text { e da Ortigão \& Cia. (1879-), presidente } \\
\text { da Caixa de Socorros D. Pedro V (1871), } \\
\text { incorporador da Cia. Comércio de Café } \\
\text { (1876) e da Cia. Carris Urbanos (1878, } \\
\text { transporte de café), diretor da Cia. } \\
\text { Nova Indústria (1884), acionista da fer- } \\
\text { rovia Cia. E. F. Príncipe do Grão Pará } \\
\text { (1886), presidente do Real Gabinete } \\
\text { Português de Leitura (1888) e conse- } \\
\text { lheiro fiscal do Banco Internacional do } \\
\text { Brasil (1888) e do Banco Industrial e } \\
\text { Mercantil do Rio de Janeiro (1888). }\end{array}$ \\
\hline $\begin{array}{l}\text { "Antônio Clemente } \\
\text { Pinto Filho, barão, } \\
\text { conde e visconde de } \\
\text { São Clemente em } \\
\text { 1868, 1882 e 1888, } \\
\text { respectivamente. }\end{array}$ & $\begin{array}{l}\text { Filho do } 1^{\circ} \text { barão de Nova Fribur- } \\
\text { go, irmão e sócio do Conde de } \\
\text { São Clemente (ambos fazen- } \\
\text { deiros em Cantagalo), genro } \\
\text { do barão de Quaraim (senador, } \\
\text { diplomata e líder do Partido Con- } \\
\text { servador), cunhado de Rodolfo } \\
\text { de Sousa Dantas (deputado e } \\
\text { ministro do Império). }\end{array}$ & $\begin{array}{c}\text { Fazendeiro em Cantagalo, sócio da } \\
\text { Friburgo e Filhos (1862-), fundador e } \\
\text { tesoureiro do Clube Agrícola (1878), } \\
\text { conselheiro fiscal da Caixa Econômica } \\
\text { e Monte de Socorro (1880), acionista } \\
\text { da Cia. Comércio e Imigração Chinesa } \\
\text { (1883) e membro da diretoria de ad- } \\
\text { ministração da Caixa de Amortização } \\
\text { (1884). }\end{array}$ \\
\hline $\begin{array}{l}\text { Antônio Tomás } \\
\text { Quartim - barão de } \\
\text { Quartim em } 1884\end{array}$ & $\begin{array}{l}\text { Filho de Antônio Tomás Quartim } \\
\text { (comerciante em Cantagalo e } \\
\text { Rio de Janeiro), sócio de Manuel } \\
\text { José Rodrigues Torres Sobrinho, } \\
\text { filho do visconde de Itaboraí (fa- } \\
\text { zendeiro, conselheiro de estado, } \\
\text { ministro de várias pastas e ban- } \\
\text { queiro) e sobrinho do barão de } \\
\text { Itambi (fazendeiro e banqueiro). }\end{array}$ & $\begin{array}{l}\text { Sócio da Soares \& Quartim (1873-75), } \\
\text { da Soares, Quatim \& Cia. (1875-87), da } \\
\text { Soares, Quartim, Silveira \& Cia. (1888-) } \\
\text { e da Soares, Quartim, Torres \& Cia. } \\
\text { (1887-88); diretor do Banco Comercial } \\
\text { (1887), deputado da Câmara Municipal } \\
\text { do Rio de Janeiro (1881), acionista da } \\
\text { Cia. E. F. Príncipe do Grão Pará (1886) } \\
\text { e da Cia. das Minas de Assuruá (1886, } \\
\text { mineradora baiana). }\end{array}$ \\
\hline
\end{tabular}




\begin{tabular}{|c|c|c|}
\hline $\begin{array}{l}\text { "Honório Augusto } \\
\text { Ribeiro }\end{array}$ & $\begin{array}{l}\text { Filho de Sebastião Antônio José } \\
\text { Ribeiro, genro do barão de Santa } \\
\text { Maria (fazendeiro da família } \\
\text { Carneiro Leão), sócio de João } \\
\text { Evangelista Teixeira Leite (fazen- } \\
\text { deiro, banqueiro em Vassouras e } \\
\text { investidor de ferrovias). }\end{array}$ & $\begin{array}{l}\text { Sócio da Teixeira Leite \& Cia. (1875- } \\
\text { 83), secretário da Cia. de Carruagens } \\
\text { Fluminenses (1875); diretor do Banco } \\
\text { Predial (1875) e da Cia. Manufatora } \\
\text { de Materiais para Construção (1875), } \\
\text { diretor da Associação de Socorro à } \\
\text { Invalidez Previdência (1876), conselhei- } \\
\text { ro fiscal da Cia. Garantia de Seguros } \\
\text { (1876), presidente da Cia. Ferro-Carril } \\
\text { de Pernambuco (1876), presidente da } \\
\text { Cia. Comércio de Café (1876), conse- } \\
\text { lheiro fiscal da de Seguros Previdente } \\
\text { (1880), presidente da Cia. União e } \\
\text { indústria (1880), membro do Centro } \\
\text { da Indústria e Comércio de Açúcar do } \\
\text { Rio de Janeiro (1887), diretor da Cia. } \\
\text { Engenhos Centrais da Paraíba do Norte } \\
\text { e Sergipe (1888). }\end{array}$ \\
\hline $\begin{array}{l}\text { Bruno Augusto da } \\
\text { Silva Ribeiro (portu- } \\
\text { guês) }\end{array}$ & $\begin{array}{l}\text { Sócio de Virgílio Rodrigues Alves } \\
\text { (fazendeiro de Guaratinguetá). }\end{array}$ & $\begin{array}{c}\text { Sócio de Bruno, Alves \& Carneiro } \\
\text { (1874-78), sócio da Bruno \& Cia. (1878-), } \\
\text { secretário do Real Gabinete Português } \\
\text { de Leitura (1873), conselheiro fiscal do } \\
\text { Banco del Credere (1888). }\end{array}$ \\
\hline
\end{tabular}

"Participaram do Clube da Lavoura e do Centro da Lavoura e do Comércio. Mantinham vínculos parentais ou de negócios.

Fonte: Coffee factorage and the emergence of a Brazilian capital market, 1850-1888 (Joseph. E.

Sweigart) ${ }^{60}$.

Os dados demonstram que o pensamento conservador e escravagista fazia parte do éthos e do habitus daqueles que, em 1880, propagandeavam a qualidade dos produtos agrícolas brasileiros nas "festas da modernidade", sob a batuta do Centro da Lavoura e do Comércio. Tratava-se praticamente das mesmas pessoas, do mesmo núcleo dirigente, ligados aos proprietários do Vale do Paraíba, com uma nova roupagem. Se as continuidades são evidentes no que compete aos intelectuais que davam direção à nova instituição, as mudanças se manifestaram nos investimentos, principalmente no que compete às companhias colonizadoras e de imigração que proliferaram. O fim da mão de obra escrava já estava no horizonte desses homens quando da fundação do centro, a briga era sobre em que circunstâncias se daria. Assim, o investimento em imigração era uma tentativa de

60 SWEIGART, Joseph. E. Coffee factorage and the emergence of a Brazilian capital market, 1850-1888.

New York: Garland, 1987. p. 286-293. 
alguns senhores de ganhar dos dois lados: com a indenização do governo (proposta defendida até o 13 maio de 1888) e com a exploração da mão de obra imigrante, inclusive sobre contratos de deslocamento e trabalho.

De início, pode-se dizer que a estratégia de mudança de nome para apagar os vínculos pessoais funcionou. No exterior, o Centro da Lavoura e do Comércio representava o Brasil com toda a pompa, sendo agraciado com diversos diplomas de honra e premiações de mérito, chamando atenção dos investidores. Seus esforços rendiam artigos positivos nos jornais internacionais. Nacionalmente, a situação era bem mais complicada. Grande parte da imprensa elogiava o Centro por promover o café e a imagem do Brasil no exterior. Porém, logo surgiram aqueles que apontavam os "descompassos" de um país escravista nas "festas da modernidade". Na segunda exposição nacional, a Gazeta de Notícias trazia a provocação:

Está inaugurada a segunda exposição de café promovida pelo Centro da Lavoura e do Comércio. [...] Nas diversas salas que percorremos vimos ao menos, além de alguns quadros representando fazendas de café, vários exemplares de instrumentos da lavoura e do trabalho agrícola. Apenas faltava ali um escravo para o quadro ser completo [...]. Não é ele também um instrumento da lavoura? ${ }^{61}$

Angelo Agostini, foi outro que não se furtou de fazer piada da situação (Figura 3).

\section{Figura 3}

\section{Descompassos do Brasil nas festas da modernidade}

Fonte: Revista Ilustrada, $1883^{62}$.

\section{Congresso Internacional}

- Queira perdoar-me, mas... com aquele negrinho não pode entrar.

- Mas é que não posso separar-me dele: é quem me veste, quem me dá de comer, quem... quem me serve em tudo afinal!

É que... Enfim, em atenção às ilustres qualidades pessoais de tão sábio,

61 Gazeta de Notícias, Rio de Janeiro, n. 243, p. 1, 23 out. 1882.

62 Revista Ilustrada, Rio de Janeiro, ano 8, n. 347, p. 8, 30 jun. 1883. 
soberano, creio que as nações civilizadas não duvidarão em admitilo. ${ }^{63}$

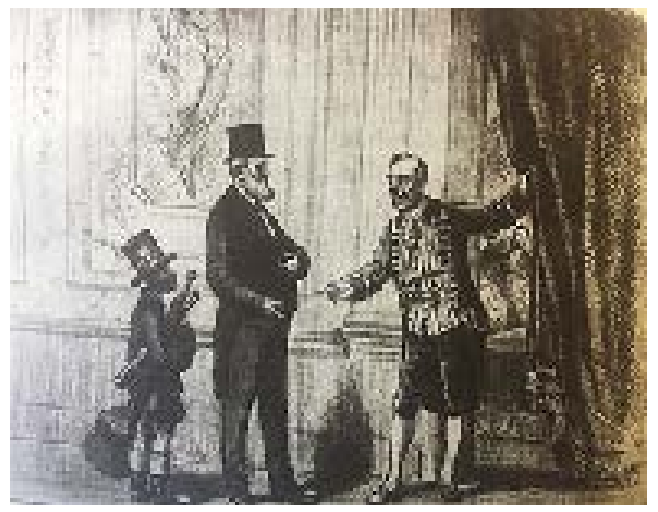

Entre os abolicionistas, no princípio, a "nova roupagem" de "verniz civilizatório" do Centro da Lavoura e do Comércio proporcionou uma trégua. O próprio José do Patrocínio buscou o diálogo por intermédio do senador liberal José Inácio Silveira da Motta e de Ramalho Ortigão. Talvez acreditasse que poderia convencê-los da abolição incondicional ${ }^{64}$. Contudo, a partir de 1883 , com a fundação da Confederação Abolicionista, a abolição no Ceará e no Amazonas, e a apresentação do projeto do liberal Souza Dantas na Câmara (1884), que pautava a libertação sem indenização dos sexagenários, as possibilidades de diálogo se extinguiram ${ }^{65}$. O "verniz civilizatório" desbotou. Para aqueles senhores, tudo estava indo rápido demais.

63 Ibidem.

64 Gazeta da Tarde, Rio de Janeiro, n. 88, 20 abr. 1884.

$65 \mathrm{O}$ projeto Dantas foi apresentado à Câmara pelo deputado liberal Rodolfo Dantas e previa a liberdade incondicional e sem indenização dos escravos com mais de 60 anos a partir da data da lei. Estabelecia também que os escravos deveriam permanecer no município onde trabalhavam, mas podendo escolher se morariam ou não na propriedade de seus antigos senhores. A proposta recebeu forte oposição, tanto de membros do seu partido, quanto dos conservadores, mas foi acolhida pelos abolicionistas. Como argumenta Mendonça, a não indenização colocava em xeque a legitimidade da escravidão e a legalidade do domínio senhorial. Assim, abolicionistas e senhores disputavam com todas as suas armas a inclusão ou não da indenização. Devido às críticas dos deputados e buscando evitar que o projeto fosse reprovado, Dantas pediu ao imperador a dissolução da Câmara e a convocação de novas eleições, o que ocorreu em setembro de 1884. A 
O Centro da Lavoura e do Comércio contra-atacou. Utilizou do Diário do Brazil ${ }^{66}$, periódico favorável à causa senhorial, para convocar um congresso em julho de 1884 com o claro objetivo de frear o movimento abolicionista ${ }^{67}$. A conexão com os senhores da bacia do Paraíba era clara e, na mesma edição, os fazendeiros de Paraíba do Sul, Juiz de Fora e São João Nepomeceno se propunham a mandar representantes:

Se o Centro do Comércio e Lavoura entender que uma reunião é conveniente e oportuna, se dirigirá aos lavradores e comerciantes dos diversos municípios das referidas províncias, para que estes nomeiem delegados, que formarão com o Centro do Comércio e Lavoura um congresso que estude, discuta e proponha ao governo meios que melhor lhes pareçam afim de opor uma barreira aos desmandos dos pseudos-abolicionistas, cujas doutrinas subversivas, são uma ameaça não só a nossa propriedade como também as nossas famílias. ${ }^{68}$

No Congresso de 1884, foi escolhido um comitê central responsável por combater o movimento abolicionista e promover as articulações necessárias para a defesa dos interesses da agricultura ${ }^{69}$. Ao

nova composição legislativa também não se mostrou favorável ao projeto. Como consequência, o ministro Dantas foi demitido e o senador José Antonio Saraiva foi convidado para compor o novo gabinete. O projeto Saraiva, que acabou sendo aprovado com poucas mudanças por Cotegipe em 28 de setembro de 1885, transformava aspectos importantes da proposta de Dantas: os escravos seriam livres ao completarem 60 anos, mas deveriam prestar serviços aos antigos senhores até os 65 anos a título de indenização e tinham a obrigatoriedade de permanecerem na propriedade do senhor, mesmo após a prestação de serviços, salvo autorizações justificadas MENDONÇA, Joseli. Op. Cit.

66 Diário do Brazil, Rio de Janeiro, n. 118, p. 1, 25 maio 1884,. "Centro da Lavoura e Comercio - O movimento, quase unanime, dos lavradores e comerciantes do interior, no sentido de organizarem associações consagradas à defesa dos seus interesses, aos progressos da sua indústria [...] convida os representantes dessas associações a reunirem-se no dia $1^{\circ}$ de julho, na casa do Centro da Lavoura e Comercio, à rua Municipal n. 11, às 11 horas da manhã, em sessão preparatória dos assumptos que devem ser considerados em sucessivas sessões".

67 Gazeta da Tarde, Rio de Janeiro, 26 maio 1884. O autor não diz o dia de junho, mas é interessante pontuarmos que o projeto Dantas foi apresentado à Câmara em 15 de junho, demonstrando a rápida reação dos membros do Centro da Lavoura e do Comércio.

68 Diário do Brazil, Rio de Janeiro, p. 1, 25 maio 1884.

69 PANG, Laura. Op. Cit., p. 533. 
todo, compareceram ao evento 49 representações de clubes da lavoura municipais, sendo 34 do Vale do Paraíba e da Zona da Mata e o restante do oeste paulista. ${ }^{70}$

Como resposta, o jornal abolicionista Gazeta da Tarde subiu o tom e se referiu ao centro como "fazendeiros e comissários do café, interessados em manter o braço escravo, a grande propriedade, a lavoura hipotecada"71. Assim, denunciou a articulação direta do centro com os clubes da lavoura municipais, extremamente violentos na luta contra o abolicionismo ${ }^{72}$. O que se pretendia escondido, na verdade, já era sabido.

\section{Sobre a dinâmica política imperial: a título de conclusão}

Em 16 de novembro de 1884, proferindo um discurso em Madalena, Pernambuco, Joaquim Nabuco conectou os dirigentes do Centro da Lavoura ao "navio apodrecido da escravidão" e afirmou: "não está no espírito da lavoura escravista auxiliar coisa alguma”. A artilharia era pesada e não se referia somente à resistência inflamada ao projeto Sousa Dantas apresentado no parlamento. Nabuco lançou fogo sobre o custeio das exposições nacionais e internacionais:

Os lavradores e comissários do sul gabavam-se de ter feito na Europa esplêndidas exposições de café. Todos acreditávamos que era à custa deles, mas no Rio de Janeiro tive ocasião de descobrir o segredo desse primeiro cometimento de uma classe entorpecida pela escravidão e incapaz de esforço mesmo em proveito próprio. As célebres exposições de café do Centro da Lavoura e do Comércio eram feitas pelo Ministério da Agricultura sem que o Parlamento tivesse votado fundos para esse fim. Eram pretextos para títulos e condecorações, custosamente elaboradas à custa da subvenção secreta. Assim, sim; mas fora dos dinheiros públicos a agricultura como classe não realizou ainda coisa alguma, nem em benefício de seus produtos, nem

70 Dentre estes, estavam representações de Paraíba do Sul, Vassouras, Valença, Resende, Barra Mansa, Campos, Juiz de Fora, Campinas, Jundiaí, Amparo, Limeira, Mogimirim, Rio Claro, São Carlos do Pinhal etc. (Ibidem, p. 338, 349).

71 Gazeta da Tarde, Rio de Janeiro, 26 maio 1884.

72 Gazeta da Tarde, Rio de Janeiro, 18 ago. 1884. 
em benefício do território que possui ou comunhão a que pertence. ${ }^{73}$

As palavras de Nabuco apontam um elemento importante do funcionamento da política imperial: a íntima relação dos proprietários, negociantes e financistas que compunham a classe senhorial, principalmente do centro-sul, com a coroa. Muito embora os estadistas tivessem autonomia em relação aos fazendeiros, defendiam um projeto de nação construído em função dos interesses senhoriais e o executavam como interesses nacionais ${ }^{74}$. Ao apoiar o Brasil nas exposições internacionais, o Centro da Lavoura e do Comércio estava representando os negócios de seus próprios dirigentes, sócios e integrantes. Queriam uma saída para a crise do café e da segunda escravidão por meio do aumento das exportações para novos mercados e, para tanto, receberam ajuda da Coroa, que dependia política e economicamente de seu apoio.

Esse exemplo é emblemático para fazermos uma crítica ao conceito de "dialética da ambiguidade" colocado por José Murilo de Carvalho $^{75}$, pois demonstra que não havia um descompasso de propósitos entre a "elite política imperial" (definida pelo autor como antiescravista) e a classe proprietária rural. Mesmo quando o governo central anunciou que o Brasil não participaria das próximas exposições internacionais, entregou a incumbência àqueles que não desvirtuariam do caminho traçado: as frações da classe senhorial lotadas na bacia do Paraíba. Podia fazê-lo porque seus propósitos eram congruentes, não havendo perigo de mudança de direção. E, como acusou Nabuco corretamente, tal transferência de responsabilidade foi custeada com recursos públicos e sem a obrigatoriedade de aprovação da Câmara,

73 NABUCO, Joaquim. Campanha abolicionista no Recife. Brasília, DF: Senado Federal, 2005. p. 115, grifo nosso.

74 MATTOS, Ilmar. Op. Cit.; SALLES, Ricardo. E o vale... Op. Cit.

75 CARVALHO. José Murilo de. O teatro de sombras: a política imperial. 4. ed. Rio de Janeiro: Civilização Brasileira, 2003. 
através do Ministério da Agricultura, mas propagandeada como investimento privado ${ }^{76}$.

Ao ocupar os espaços antes destinados ao Estado, os grandes senhores de terras e escravos os usavam a seu favor. De uma forma ou de outra, perpetuava-se o entrelaçamento das esferas pública e privada, fortalecia-se o poder senhorial e, por consequência, os negócios do café. A coroa não saía perdendo nesse processo, já que mais de 70\% de suas receitas advinham de impostos diretos ou indiretos gerados pela rubiácea. O caso das exposições internacionais é uma excelente lente para observar esse dispositivo da política imperial. Por meio delas, os integrantes da classe senhorial se valeram do estado para projetar suas transações no exterior, receberem títulos de nobreza e cargos no governo (todos os quatro diretores do Centro da Lavoura e do Comércio titulados foram condecorados na década de 1880), além de construírem uma prestigiosa imagem pública de beneméritos até mesmo num momento em que o mundo senhorial tendia a ruir devido à crise da segunda escravidão ${ }^{77}$.

\section{Bibliografia}

ALONSO, Angela. Flores, votos e balas: o movimento abolicionista brasileiro (1868-1888). Sao Paulo: Companhia das Letras, 2015.

76 Desta relação mais direta com o estado, desde 1882, o Centro da Lavoura passou a atuar junto ao legislativo e ao executivo para obter: " $1^{\circ}$ Redução de Tarifa das estradas de ferro. $2^{\circ}$ Redução dos direitos de exportação para os produtores agrícolas do pais. $3^{\circ}$ Tratados de comercio com países que mais interessem ao Brasil. $4^{\circ}$ Reforma da lei hipotecaria. $5^{\circ}$ Meios práticos de promover a imigração estrangeira. $6^{\circ}$ Penhor mercantil de produtos e valores agrícolas. $7^{\circ}$ Prêmios de animação à agricultura e propaganda dos respectivos produto" (Diário do Brazil, Rio de Janeiro, 13 abr. 1882). No mesmo ano, a Gazeta da Tarde noticia a realização de reuniões fechadas de membros do Centro da Lavoura e do Comércio com ministros: "Exposições de Produtos Brasileiros - A diretoria do Centro da Lavoura e do Comercio teve ontem uma larga conferência com o Sr. Ministro da agricultura, a qual assistiram os diretores d'aquela secretaria de Estado. [...] A satisfação dos diretores do Centro da lavoura, e a confiança com que os reanimou o Sr. Ministro da agricultura, é o mais grato prenuncio de uma gestão útil n'esta parte tão grande de seus trabalhos [...] Desde já, porém, é de rigor confessar a valia do primeiro passo projetado, e já em via de execução: a exposição de produtos do Brasil em Amsterdam" (Gazeta da Tarde, Rio de Janeiro, 20 out. 1882).

77 O título de barão de Araújo Maia lhe foi concedido pelo governo imperial do Brasil após expedição comercial à Rússia. A pedido do Centro da Lavoura e do Comércio, foi assinado o Decreto $n^{\circ}$ 
BEIGUELMAN, Paula. A Formacao do povo no complexo cafeeiro: aspectos politicos. Sao Paulo: Pioneira, 1977.

BLACKBURN, Robin. Por que segunda escravidao? In: MARQUESE, Rafael; SALLES, Ricardo (org.). Escravidao e capitalismo historico no seculo XIX: Cuba, Brasil e Estados Unidos. Rio de Janeiro: Civilizacao Brasileira, 2016. p. 13-54.

CANO, Jefferson. Liberdade, cidadania e politica de emancipacao escrava. Revista de Historia, Sao Paulo, n. 136, p. 107-120, 1997.

CARVALHO, Jose Murilo (org.). Congresso Agricola: edicao fac-similar dos Anais do Congresso Agricola, realizado no Rio de Janeiro, em 1878. Rio de Janeiro: Fundacao Casa de Rui Barbosa, 1988.

CARVALHO. Jose Murilo de. O teatro de sombras: a politica imperial. 4. ed. Rio de Janeiro: Civilizacao Brasileira, 2003.

CONRAD, Robert. Os ultimos anos da escravatura no Brasil. 2. ed. Rio de Janeiro: Civilizacao Brasileira, 1978.

COSTA, Emilia Viotti da. A Abolicao. 8. ed. Sao Paulo: Editora Unesp, 2008.

D'OlIVEIRA, Luiz Rodrigues. A exposicao do Clube da Lavoura em Franca em 1878. Paris: Typ. Georges Clarmerot, 1878.

EISENBERG, Peter. A mentalidade dos fazendeiros no Congresso Agricola de 1878. In: AMARAL LAPA, Jose Roberto do (org.). Modos de producao e realidade brasileira. Rio de Janeiro: Vozes, 1980. p. 167-194.

El YUSSEF, Alan; ESTEFANES, Bruno; PARRON, Tamis. Vale expandido: contrabando negreiro, consenso e regime representativo no Imperio do Brasil. In: MUAZE, Mariana; SALLES, Ricardo (org.). O Vale do Paraiba e o Imperio do Brasil nos quadros da segunda escravidao. Rio de Janeiro: 7Letras, 2015. p. 130-158.

ELIAS, Norbert. O processo civilizador. Rio de Janeiro: Zahar, 1993. v. 1-2.

FERREIRA, Marieta de Moraes. A crise dos comissarios de cafe do Rio de Janeiro. 1977. Dissertacao (Mestrado em Historia), Universidade Federal Fluminense, Niteroi, 1977.

FOOT HARDMAN, Francisco. Trem-fantasma: a ferrovia Madeira-Mamore e

9067, de 24 de novembro de 1883, que criava diplomas de distinção para serem concedidos por ocasião da exposição agrícola, dirigida pelo Centro da Lavoura e Comércio (BRASIL. Decreto ${ }^{\circ}$ 9.067, de 24 de novembro de 1883. Coleção de Leis do Império do Brasil, Rio de Janeiro, v. 2, p. 317, 1883. Disponível em: https://bit.ly/3012tuM. Acesso em: 8 maio 2020). 
a modernidade na selva. Sao Paulo: Companhia das Letras, 2005.

GEBARA, Ademir Gebara. O mercado de trabalho livre no Brasil. Sao Paulo: Brasiliense, 1986

LAGE, Lana. Rebeldia negra e abolicionismo. Rio de Janeiro: Achime, 1981.

LIMA, Ivana; GRINBERG, Keila; REIS, Daniel A. (org.). Instituicoes nefandas: o fim da escravidao e da servidao no Brasil, nos Estados Unidos e na Russia. Rio de Janeiro: Fundacao Casa de Rui Barbosa, 2018.

MACHADO, Maria H. O plano e o panico: os movimentos sociais na decada da abolicao. Sao Paulo: Edusp; Rio de Janeiro: Editora UFRJ, 2010.

MACHADO, Marina Monteiro; MARTINS, Monica de Souza Nunes. A modernidade nas teias da floresta: o Brasil na exposicao Universal da Filadelfia de 1876. Geosul, Florianopolis, v. 32, n. 65, p. 68-86, nov. 2017.

MARQUESE, Rafael. The Civil War in the United States and the crisis of slavery in Brazil. In: DOYLE, Don Harrison (org.). American Civil Wars: the United States, Latin America, Europe, and the crisis of the 1860's. Chapel Hill: University of North Carolina Press, 2017. p. 222-245.

MARQUESE, Rafael; TOMICH, Dale. O Vale do Paraiba escravista e a formacao do mercado mundial do cafe no seculo XIX. In: MUAZE, Mariana; SALLES, Ricardo. O Vale do Paraiba e o Imperio do Brasil nos quadros da segunda escravidao. Rio de Janeiro: 7Letras, 2015. p. 21-56

MATTOS, Ilmar. O tempo saquarema. Rio de Janeiro: Acess, 1986.

MENDONCA, Joseli. Entre a mao e os aneis. Campinas: Editora Unicamp, 1999.

MIRANDA, Bruno da Fonseca. O Vale do Paraiba cafeeiro contra a Lei do Ventre Livre, 1865-1871. 2018. Dissertacao (Mestrado Historia Social) - Universidade de Sao Paulo, Sao Paulo, 2018.

MONNERAT, Tanize. Abolicionismo em acao: o jornal Vinte e Cinco de Marco em Campos dos Goytacazes (1884-1888). Rio de Janeiro: Essentia, 2015.

MOTTA, Jose Flavio; LOPES, Luciana Suarez. Os cisnes cantam e a onda verde passa: os congressos agricolas de 1878 e a demanda da lavoura por capitais. Economia e Sociedade, Campinas, v. 28, n. 2, p. 587-614, 2019.

MUAZE, Mariana. A escravidao no Vale do Paraiba pelas lentes do fotografo Marc Ferrez. In: CARVALHO, Jose Murilo de; BASTO, Lucia (org.). Dimensoes e fronteiras do estado brasileiro no Oitocentos. Rio de Janeiro: Eduerj, 2014. p. 191-214 
MUAZE, Mariana. As memorias da viscondessa: familia e poder no Brasil imperio. Rio de Janeiro: Zahar, 2008.

MUAZE, Mariana. Violencia apaziguada: escravidao e cultivo do cafe nas fotografias de Marc Ferrez (1882-1885). Revista Brasileira de Historia, Sao Paulo, v. 37, n. 74, p. 33-62, 2017.

MUAZE, Mariana; SALLES, Ricardo (org.). A segunda escravidao e o Imperio do Brasil e em perspectiva historica. Sao Leopoldo: Casa Leiria, 2020.

MUAZE, Mariana; SALLES, Ricardo (org.). O Vale do Paraiba e o Imperio do Brasil nos quadros da segunda escravidao. Rio de Janeiro: 7Letras, 2015.

NABUCO, Joaquim. Campanha abolicionista no Recife. Brasilia, DF: Senado Federal, 2005.

PANG, Laura. The State and agricultural clubs of Imperial Brazil 1860-1889. 1981. Tese (Doutorado em Historia) - Vanderbilt University, Nashville, 1981.

PENA, Eduardo Spiller. Pajens da casa imperial. Campinas: Editora Unicamp, 2005.

PESAVENTO, Sandra J. Exposicoes universais, espetaculo da modernidade do seculo XIX. Sao Paulo: Hucitec, 1997.

PESSOA, Thiago Campos. O Imperio da escravidao: o complexo Breves no vale do cafe (Rio de Janeiro, 1850-1888). Rio de Janeiro: Arquivo Nacional, 2015.

PINTO, Ana Flavia Magalhaes. Escritos de liberdade: literatos negros, racismo e cidadania no Brasil oitocentista. Campinas: Editora Unicamp, 2018.

SALLES, Ricardo. E o vale era escravo. Rio de Janeiro: Civilizacao Brasileira, 2008.

SALLES, Ricardo. Resistencia escrava e abolicao na provincia do Rio de Janeiro: o partido abolicionista. In: LIMA, Ivana; GRINBERG, Keila; REIS, Daniel A. (org.). Instituicoes nefandas: o fim da escravidao e da servidao no Brasil, nos Estados Unidos e na Russia. Rio de Janeiro: Fundacao Casa de Rui Barbosa, 2018. p. 266-293.

SANTOS, Claudia. O ativismo politico da Confederacao Abolicionista antes e depois do 13 de maio. In: LIMA, Ivana; GRINBERG, Keila; REIS, Daniel A. (org.). Instituicoes Nefandas: o fim da escravidao e da servidao no Brasil, nos Estados Unidos e na Russia. Rio de Janeiro: Fundacao Casa de Rui Barbosa, 2018. p. 294-326.

STEIN, Stanley. Grandeza e decadencia do cafe no vale do Paraiba. Sao Paulo: 
Brasiliense, 1961.

SWEIGART, Joseph Earl. Financing and making Brazilian exportation agriculture: the coffee factors of Rio de Janeiro. 1980. Tese (Doutorado em Historia) - University of Texas, Austin, 1980.

SWEIGART, Joseph. E. Coffee factorage and the emergence of a Brazilian capital market, 1850-1888. New York: Garland, 1987.

TOMICH, Dale. Sob o prisma da escravidao: trabalho, capitalismo e economia mundial. Sao Paulo: Edusp, 2011.

TURAZZI, Maria Ines. Poses e Trejeitos: a fotografia e as exposicoes na era do espetaculo. Rio de Janeiro: Funart: Rocco, 1995.

VALVERDE, Valverde. A fazenda escravocrata de cafe. Revista Brasileira de Geografia, Rio de Janeiro, ano 29, n. 1, p. 37-81, 1967.

\section{Documentos impressos e jornais consultados}

BONIFACIO, Jose. Representacao à Assembleia Geral Constituinte e Legislativa do Imperio do Brasil Sobre a Escravatura. Rio de Janeiro: Typographia de J. E. S. Cabral, 1840.

BRASIL. Decreto n ${ }^{\circ}$ 9.067, de 24 de novembro de 1883. Colecao de Leis do Imperio do Brasil, Rio de Janeiro, v. 2, p. 317, 1883. Disponivel em: https://bit. ly/3012tuM. Acesso em: 8 maio 2020.

BREVE noticia sobre a primeira exposicao do Cafe do Brasil. Rio de Janeiro: Clube da Lavoura e do Comercio, 1882.

CATALOGO dos produtos nacionais e industriais remetidos para a exposicao universal de Londres. Londres: Typ. de C. Whiting Baeufort, 1862.

CORNELI, Rene. Anvers et L'Exposition Universalle. 12. ed. Bruxelles: Typographie \& Lithographie Ad. Mertens, 1886.

CUNHA, Antonio Luiz Fernandes da. Relatorio geral da exposicao nacional de 1861 e relatorios dos jurys especiaes, colligidos e publicados por deliberacao da Commissao Directora. Rio de Janeiro: Typographia do Diario do Rio de Janeiro, 1862.

D'OLIVEIRA. Luiz Rodrigues. Exposicao do Club da Lavoura em Franca em 1878. Paris: Typographie Georges Charmerot, 1878. Relatorio apresentado à diretoria.

DIARIO DE NOTICIAS. Rio de Janeiro: [s. n.], 1877. 
DIARIO DO BRAZIL. Rio de Janeiro: [s. n.], 1882-1884.

DIARIO DO RIO DE JANEIRO. Rio de Janeiro: [s. n.], 1862-1877.

GAZETA DA TARDE. Rio de Janeiro: [s. n.], 1880-1884.

LE BRESIL à l'Exposition Internacionale de St. Petersburg. St. Petersburg: Imprimerie Trenke et Fusnot, 1884.

ORTIGAO, Ramalho. Notas de viagem: Paris e a exposicao universal (1878-79). Rio de Janeiro: Typ. Gazeta de Noticias, 1879.

PARANHOS JR., Jose Maria da Silva. Relatorio da Exposicao Brasileira de Sao Petersburgo (2/6/1884). Cadernos do CHDD, Brasilia, DF, ano 12, n. 22, 2013.

PRADO, conselheiro A da. Exposicao Universal de Antuerpia (Anvers): relatorio. Rio de Janeiro: Typ. Imperial Nacional, 1886.

REVISTA ILUSTRADA. Rio de Janeiro: [s. n.], 1883.

SILVA, Jose Bonifacio de A. Representacao a Assembleia Geral Constituinte e Legislativa do Imperio do Brasil Sobre a Escravatura. Rio de Janeiro: Typographia de J. E. S. Cabral, 1840.

Recebido em: 01/03/2021 - Aprovado em: 27/04/2021 